\title{
EFEK GANDA PENGELOLAAN WAKAF UANG
}

\author{
Rozalinda \\ Fakultas Syariah IAIN Imam Bonjol \\ Jl. Mahmud Yunus, Lubuk Lintah, Padang, 25153 \\ e-mail: roza_linda32@yahoo.com
}

\begin{abstract}
Abstrak: Selama ini pemanfaatan wakaf cenderung tidak produktif dan mengabaikan kemungkinan potensi untuk kesejahteraan umum. Tulisan ini mendiskusikan perubahan dan implikasi yang timbul dengan dikeluarkannya Undang-undang Nomor 41 tahun 2004 tentang Wakaf. Penulis mengemukakan bahwa wakaf uang dapat berperan dalam menunjang proses pembangunan secara menyeluruh, baik pembangunan sumber daya manusia, maupun ekonomi dan sosial. Investasi wakaf uang dapat disalurkan untuk membantu biaya operasional lembaga-lembaga pendidikan, kesehatan dan sosial. Di sinilah wakaf uang berperan sebagai salah satu sumber pendanaan alternatif untuk peningkatan kesejahteraan umat. Menurut penulis, introduksi UndangUndang ini menjadi momentum pemberdayaan wakaf secara produktif.
\end{abstract}

\begin{abstract}
The Multiplier Effects of Currency Endowment Management. The employment of wakaf or endowment thus far tends to be unproductive disregarding the possibility of its potential for the public interest. This writing discusses changes and implication brought by the introduction of Regulation No. 41/2004 concerning Wakaf. The author maintains that currency endowment may function to supporting the process of development throroughly, both in human resources and social economy. Currency endowment investment may be distributed as a mean of assisting operational funding of educational, health and social institutions. It is on this that currency endowment plays the role as an alternative financial resource for the betterment of social prosperity. According to the author, the introduction of this regulation would become an avenue for empowering endowment productively.
\end{abstract}

Kata Kunci: wakaf uang, ekonomi umat, UU No. 41/2004

\section{Pendahuluan}

Selama ini, peruntukan wakaf di Indonesia kurang mengarah pada pemberdayaan ekonomi umat, cenderung terbatas hanya untuk kepentingan kegiatan ibadah, pendidikan, dan pemakaman semata, kurang mengarah pada pengelolaan wakaf produktif. Dengan diaturnya wakaf uang dalam Undang-undang Nomor 41 Tahun 2004 tentang Wakaf, sektor 
wakaf dapat lebih difungsikan ke arah peningkatan kesejahteraan sosial ekonomi umat. Undang-undang Nomor 41 Tahun 2004 Tentang Wakaf ini menjadi momentum pemberdayaan wakaf secara produktif sebab di dalamnya terkandung pemahaman yang komprehensif dan pola manajemen pemberdayaan potensi wakaf secara modern.

Dalam undang-undang ini, konsep wakaf mengandung dimensi yang sangat luas. Wakaf mencakup harta tidak bergerak maupun yang bergerak, termasuk wakaf uang yang penggunaannya sangat luas, tidak terbatas untuk pendirian tempat ibadah dan sosial keagamaan, tetapi juga untuk pemberdayaan ekonomi umat. Formulasi hukum yang demikian, jelas menunjukkan adanya suatu perubahan yang sangat revolusioner dalam wakaf.

Pengesahan undang-undang ini merupakan langkah strategis untuk meningkatkan kesejahteraan umum. Meningkatkan peran wakaf tidak hanya sebagai pranata keagamaan saja, tetapi juga memiliki kekuatan ekonomi yang potensial untuk memajukan kesejahteraan umum. Dari sini nampak jelas bagaimana kepentingan kesejahteraan sosial sangat kuat memengaruhi proses regulasi di bidang perwakafan. Semangat pemberdayaan potensi wakaf secara produktif dan profesional yang dikumandangkan undang-undang wakaf ini adalah untuk kepentingan kesejahteraan umat manusia di bidang ekonomi, pendidikan, kesehatan, maupun bidang sosial keagamaan lainnya.

Dengan dikembangkannya wakaf uang, akan didapat sejumlah keunggulan, di antaranya adalah: Pertama, wakaf uang jumlahnya bisa bervariasi sehingga seseorang yang memiliki dana terbatas sudah bisa memberikan dana wakafnya tanpa harus menunggu menjadi orang kaya atau tuan tanah terlebih dahulu, sehingga dengan program wakaf uang akan memudahkan wakif untuk berwakaf. Kedua, melalui wakaf uang, aset-aset wakaf yang berupa tanah-tanah kosong bisa dimanfaatkan dengan membangun gedung atau sarana lain yang lebih produktif untuk kepentingan umat. Ketiga, dana wakaf uang juga bisa membantu sebagian lembaga-lembaga pendidikan Islam yang cash flow-nya sangat kekurangan. Pada gilirannya umat Islam dapat lebih mandiri dalam mengembangkan dunia pendidikan tanpa harus terlalu tergantung pada anggaran pendidikan negara yang memang semakin lama semakin terbatas. Keempat, dana wakaf uang bisa memberdayakan usaha kecil. Dana yang terkumpul dapat disalurkan kepada para pengusaha dan bagi hasilnya digunakan untuk kepentingan sosial. ${ }^{1}$

Ini membuktikan bahwa pengelolaan wakaf uang memiliki nilai ekonomi yang strategis. Tidak ditentukannya batasan dan kadar wakaf dalam perspektif fiqih memberi kesempatan kepada setiap orang untuk berpartisipasi dalam pembangunan ekonomi umat, tanpa harus menunggu menjadi kaya terlebih dahulu. Karena itu, seorang wakif dapat saja mewakafkan uangnya kapan saja dan dalam jumlah berapa saja. Berbeda dengan zakat yang ditentukan jumlah dan kadarnya, wakaf uang merupakan perbuatan sunat yang batas dan jumlahnya dibebaskan bagi wakif untuk mengeluarkannya seperti halnya

${ }^{1}$ Isbir, "Wakaf Tunai," http://www.bimasislam.depag.go.id, 19 Desember 2007, 10.53 WIB. 
sedekah. Seharusnya konsep ini dapat menjadi spirit keagamaan yang mendorong masyarakat untuk berwakaf sesuai dengan kemampuannya sehingga jumlah wakif akan terus bertambah dan jumlah dana wakaf yang terhimpun pun meningkat. Dari keunggulan wakaf uang tersebut, jelas pengelolaan wakaf uang menjadi sangat penting karena sarat dengan dimensi ekonomi yang memberikan pengaruh terhadap penciptaan keadilan distributif dan keadilan sosial.

\section{Muatan Ekonomi dalam Wakaf Uang}

Pengelolaan wakaf uang sangat strategis dan dapat digunakan untuk pembangunan ekonomi umat. Dari perspektif ekonomi, menurut Duddy Roesmara Donna dan Mahmudi dalam The Dynamic Optimization of Cash Waqf Management: an Optimal Control Theory Approach, wakaf dapat dilihat sebagai simpanan dan investasi secara bersamaan. Wakaf dari sudut pandang ekonomi bisa dikatakan sebagai instrumen saving sekaligus prosperity (kemakmuran), yakni sebagai dana yang potensial untuk diinvestasikan dalam asset produktif yang dapat memberikan hasil atau pendapatan. Ini yang dikatakan dengan wakaf uang mengombinasikan tindakan saving dan investasi secara bersamaan. Wakaf dapat juga diperlakukan sebagai investasi yang memberikan pengembalian investasi yang dapat digali untuk memberikan manfaat bagi masyarakat. Dari perspektif ini, wakaf dapat dilihat sebagai sarana untuk menciptakan multiplier effects (efek ganda) baik dari sisi ekonomi maupun sosial. Dengan melaksanakan wakaf, berarti wakif mengorbankan kesempatan konsumsi hari ini dan secara berbarengan meletakkannya sebagai investasi yang dapat meningkatkan akumulasi modal sosial dalam ekonomi untuk tujuan peningkatan pelayanan sosial dan pendapatan masa yang akan datang. ${ }^{2}$ Wakaf uang, dipandang sebagai salah satu solusi yang dapat membuat wakaf menjadi lebih produktif. Karena uang di sini tidak lagi dijadikan sebagai alat tukar menukar saja, lebih dari itu merupakan modal yang siap dijadikan sebagai alat produksi.

Sejalan dengan itu, dalam Islam, perilaku konsumsi seseorang dimodifikasi dengan mempertimbangkan karakteristik konsumsi berdasarkan ketentuan syariah. Dengan adanya pengeluaran wakaf uang, pola konsumsi masyarakat (wakif) akan berubah ke arah pola konsumsi produktif. Uang yang diwakafkan akan lebih bermanfaat secara ekonomis kepada mustahik karena oleh nazir wakaf diinvestasikan untuk kegiatan-kegiatan produktif, misalnya disalurkan sebagai modal kerja bagi masyarakat yang berpenghasilan rendah dengan skema mudhârabah atau musyârakah.

Jika potensi wakaf uang dalam meningkatkan pertumbuhan dan pemerataan ekonomi dapat diwujudkan, lebih lanjut potensi ini akan mampu menjaga stabilitas politik. Investasi dana wakaf melalui sektor ril akan mengarah pada keseimbangan antara uang wakaf

${ }^{2}$ Duddy Roesmara Donna dan Mahmudi, "The Dynamic of Cash Waqf Management an Optimal Control Theory Approach," http://psekp.ugm.ac.id, h. 2, Diunduh 18 Juni, 2007, 13.07 WIB. 
yang terhimpun dan sektor ril yang membutuhkan talangan dana. Hasil dari pengelolaan dana wakaf, dapat menjaga stabilitas politik akibat ketidakmampuan pemerintah menciptakan pertumbuhan ekonomi, yakni dengan meningkatkan taraf hidup masyarakat dari peningkatan pendapatan dan tersedianya lapangan kerja. Keadaan ini akan dapat mengurangi beban APBN pemerintah karena tingginya angka kemiskinan. ${ }^{3}$

Di samping itu, wakaf dapat dikelola untuk memenuhi kebutuhan masyarakat dengan menyediakan pelayanan sosial yang paling esensial tanpa dana dari pemerintah. Karena itu, menurut Murat Cizakca, Dosen Fakultas Administrasi Bisnis Universitas Bahcesehir Turki, pemerintah dapat menggunakan instrumen wakaf untuk menyelesaikan masalah defisit anggaran dan mengurangi utang negara. ${ }^{4}$

Gagasan wakaf uang yang dipopulerkan oleh M.A. Mannan melalui pembentukan Sosial Investment Bank Limited (SIBL) di Bangladesh yang dikemas dalam mekanisme instrumen Cash Waqf Certificate telah memberikan kombinasi alternatif solusi mengatasi masalah kesejahteraan sosial di negeri ini. Model wakaf uang adalah sangat tepat untuk mewujudkan kesejahteraan sosial. Ia juga mampu mengatasi krisis ekonomi seperti yang telah dibuktikan di Bangladesh. Model wakaf uang juga bisa mengalahkan kontroversi seputar policy pemerintah pada UKM yang belum mengena sasaran dan menyentuh inti permasalahan. Wakaf uang sangat potensial untuk menjadi sumber pendanaan abadi guna melepaskan bangsa dari jerat utang dan ketergantungan pada luar negeri. ${ }^{5}$

Menurut Ahmad Muhammad 'Abd al-'Azhim al-Jamal, peranan wakaf dalam memenuhi kebutuhan ekonomi masyarakat dapat dilihat dari beberapa segi, yakni: 1) melalui simpanan wakaf yang ditujukan untuk melayani proyek-proyek pembangunan, akan tercapai kekuatan finansial baru yang menyokong perekonomian negara. Aset-aset wakaf itu adalah kebutuhan finansial yang tetap eksis dan selalu membantu ekonomi negara; 2) membantu pendirian infrastruktur; 3) memberikan kesempatan untuk mendapatkan pekerjaan dan mengurangi pengangguran; 4) berpartisipasi dalam menambah gerakan bisnis di masyarakat. ${ }^{6}$

Adapun peranan wakaf uang dalam pemberdayaan ekonomi umat dapat dilihat pada dua hal, yaitu peningkatan pertumbuhan ekonomi dan pemeratan pertumbuhan ekonomi.

${ }^{3}$ Departemen Agama RI Direktorat Jenderal Bimbingan Islam dan Penyelengaraan Haji Direktorat Pengembangan Zakat dan Wakaf, Wakaf Tunai dalam Perspektif Hukum Islam (Jakarta: t.t., 2005), h. 111.

${ }^{4}$ Murat Cizakca, "Awqaf in History and its Implications for Modern Islamic Economic," dalam Islamic Economic Studies Vol. 6 No. 1 November 1998 (Jeddah: Islamic Research and Training Institution (IRTI) Islamic Development Bank (IDB), h. 44.

${ }^{5}$ Mustafa Edwin Nasution, "Wakaf Tunai dan Sektor Volunter: Strategi untuk Mensejahterakan Masyarakat dan Melepaskan Ketergantungan Hutang Luar Negeri," Makalah disampaikan dalam Seminar Wakaf Tunai-Inovasi Finansial Islam: Peluang dan Tantangan dalam Mewujudkan Kesejahteraan Sosial, Jakarta: 10 November 2001.

${ }^{6}$ Ahmad Muhammad 'Abd al-Azhim al-Jamal, Daur Nizhâm al-Waqfal-Islâmîfí al-Tanmiyah al-Iqtishâdiyah al-Mu'âshirah (Kairo: Dâr al-Salâm, 2007), h. 135. 


\section{Peningkatan Pertumbuhan Ekonomi}

Wakaf uang yang digunakan untuk investasi bisnis ternyata mampu meningkatkan pertumbuhan ekonomi suatu negara, yaitu mentransformasikan tabungan masyarakat menjadi modal investasi. Hal ini dapat digambarkan melalui ilustrasi berikut ini. ${ }^{7}$ Jika ada 20 juta umat Islam Indonesia dari 210 juta umat Islam Indonesia mewakafkan uangnya sebesar Rp50.000,00 maka dalam hitungan sederhana akan diperoleh dana sebesar 1 triliun rupiah. Dana wakaf itu siap untuk diinvestasikan. Jika dana itu dititipkan di bank syari'ah dengan bagi hasil 10\% pertahun, pada akhir tahun sudah ada dana segar yang siap dimanfaatkan sebesar 100 miliyar rupiah. Perhitungan ini baru untuk satu kali wakaf, lantas bagaimana kalau umat Islam Indonesia yang mewakafkan uangnya sekitar 100 juta orang dan dilakukan secara berulang-ulang untuk beberapa periode, karena wakaf dapat dilakukan kapan saja. Tentulah dana wakaf itu akan terkumpul dalam jumlah yang besar dan sangat potensial untuk menjadi sumber dana investasi bagi pengembangan ekonomi umat.

Berdasarkan ilustrasi di atas, bila 100 milyar rupiah sebagai hasil dari menginvestasikan dana wakaf 1 triliun rupiah, maka betapa banyak orang miskin akan mendapatkan manfaat dari dana tersebut melalui modal kerja. Sekian ribu anak yatim dan panti asuhan dapat disantuni, sekian puluh sekolah dapat diperbaiki, sekian balai kesehatan dapat didirikan dan sekian pedagang dan petani kecil dapat diberikan modal kerja. Wakaf uang tidak hanya bermanfaat untuk meningkatkan pertumbuhan ekonomi, namun juga mampu menciptakan pemerataan pendapatan terutama bagi masyarakat yang semula tidak memiliki peluang usaha menjadi mendapat peluang usaha, dan bagi masyarakat yang semula tidak mempunyai pendapatan menjadi memiliki pendapatan.

Melihat fenomena kemiskinan hari ini, wakaf uang sangatlah prospektif untuk membantu pemberdayaan ekonomi masyarakat miskin. Harta wakaf yang diinvestasikan dalam usaha bagi hasil (mudhârabah) membantu masyarakat yang kekurangan modal atau belum punya usaha untuk dapat meningkatkan pendapatannya. Kemudian, pendapatan bagi hasilnya disalurkan sesuai dengan tujuan wakaf. Dalam melakukan pengelolaan ini, nilai uang yang diwakafkan harus tetap utuh jumlahnya, sedangkan yang disampaikan kepada mawqûf 'alaih adalah hasil pengembangan wakaf uang tersebut. Seperti yang dinyatakan Dian Masyita et al., dana wakaf uang dapat menjadi dana pengurangan kemiskinan di Indonesia terutama melalui program micro finance. Perusahaan mikro dapat menjalankan usaha secara optimal setelah dibiayai. ${ }^{8}$ Di sinilah wakaf uang itu dapat menghapuskan kemiskinan dan meningkatkan kualitas hidup masyarakat Indonesia.

Wakaf uang menawarkan peluang untuk membantu masyarakat dalam mening-

${ }^{7}$ Departemen Agama RI, Wakaf Tunai, h. 106.

${ }^{8}$ Dian Masyita, et al., "A Dynamic Model for Cash Waqf Management as One of the Alternative Instruments for the Poverty Alleviation in Indonesia," makalah disampaikan pada The 23rd International Conference of the System Dynamics Society Massachussets Institute of Technology (MIT), Boston, Juli 17-21, 2005, h. 27. 
katkan pendapatan dari bagi hasil yang diperolehnya. Lebih lanjutnya tentunya pendapatan ini memberi dampak positif bagi perubahan kehidupan ekonomi masyarakat. Apalagi investasi dana wakaf yang disalurkan diberikan dalam bentuk dana bergulir yang dijadikan modal usaha bagi masyarakat lainnya secara berkelanjutan. Betapa banyak masyarakat yang dapat diberdayakan kehidupan ekonominya dan betapa banyak masyarakat yang dapat menikmati manfaat investasi wakaf uang, sungguh suatu instrumen keuangan Islam yang sangat potensial.

Wakaf merupakan instrumen finansial Islam yang memiliki keterkaitan langsung secara fungsional dengan upaya pemecahan masalah-masalah sosial dan ekonomi, seperti pemberdayaan ekonomi umat, pengentasan kemiskinan, dan peningkatan kualitas sumber daya manusia. Dengan demikian wakaf sesungguhnya memiliki peranan yang cukup besar dalam mewujudkan tata sosial yang berkeadilan. Dalam jangkauan yang lebih luas, kehadiran wakaf uang dapat dirasakan manfaatnya untuk meningkatkan taraf hidup masyarakat di bidang ekonomi, terutama sekali jika wakaf dikelola dengan manajemen yang rapi, teratur dan profesional disertai kualitas para pengelolanya.

\section{Pemeratan Pertumbuhan Ekonomi}

Wakaf uang sering dipandang sebagai salah satu solusi yang dapat membuat wakaf menjadi lebih produktif. Uang wakaf dapat digunakan sebagai modal yang siap untuk diproduktifkan. Salah satu kelebihan wakaf uang adalah pemberian peluang bagi penciptaan investasi di bidang ekonomi, termasuk bidang keagamaan, pendidikan, dan pelayanan sosial. Wakaf dalam bentuk ini lebih meluas sifatnya, dari pada sekadar benda bergerak yang lainnya. ${ }^{9}$

Melalui wakaf uang (cash waqf) aset-aset wakaf yang ada, seperti tanah kosong yang tidak produktif, dapat dimanfaatkan untuk pembangunan toko atau rumah sewa ataupun diolah menjadi lahan pertanian. Lahan tersebut dapat dikelola secara mudhârabah atau ijârah kemudian hasilnya dapat disalurkan kepada mawqûf'alaih. Dengan potensi dana yang cukup besar pada contoh perhitungan di atas, cara pengelolaan dana wakaf seperti ini dapat mengatasi masalah pengangguran. Orang yang tidak mempunyai pekerjaan yang tetap atau kekurangan dana dalam berusaha dapat mengatasi masalahnya dengan mendapat pembiayaan dana dari lembaga wakaf yang ada. Seperti yang telah dibuktikan Tabung Wakaf Indonesia (TWI) Dompet Dhu'afa, lembaga ini menyalurkan dana wakaf produktifnya kepada usaha kecil menengah yang tersebar di Indonesia, baik dalam sektor perdagangan, perkebunan maupun peternakan.

Menurut al-Jamal, wakaf dapat mengatasi stagnasi (kelesuan) ekonomi. Wakaf memiliki peran efektif dalam menekan unsur-unsur produktivitas yang terabaikan, memiliki kemampuan

9http://www.halalguide.info, "Wakaf Produktif," 6 Juni, 2007, 18.54 WIB. 
maksimal dalam memerangi pengangguran, serta punya pengaruh jelas dalam pengalokasian pendapatan dan kekayaan. Usaha wakaf dalam pembangunan dan pemusatan eksperimen di bidang tersebut secara terus menerus membuat lembaga-lembaga wakaf berkembang menjadi suatu sistem yang bisa menghadapi krisis. Wakaf memenuhi standar stabilitas moneter minimal untuk beberapa bidang pembangunan sosial. Memelihara stabilitas moneter dari fluktuasi pendanaan pemerintah yang terkadang menghadapi krisis karena minimnya pendanaan atau meningkatnya pembelanjaan karena biaya tidak terduga. ${ }^{10}$ Dengan demikian wakaf merupakan payung pelindung dari fluktuasi dan badai ekonomi.

Investasi wakaf sebetulnya memiliki keunikan tersendiri yang membedakannya dengan investasi lain. Pertama, investasi wakaf walaupun ditujukan pada sektor produktif yang dapat mendatangkan keuntungan secara pasti (provitable). Namun, pengembangan wakaf tidak didasarkan pada target pencapaian keuntungan bagi pemodal saja, tetapi lebih mengedepankan unsur birr (kebajikan). Keunikan inilah yang membedakan investasi wakaf dengan investasi di sektor pemerintah (public sector) maupun sektor swasta (private sector). Begitu uniknya sektor ini, Monzer Kahf memasukkan wakaf sebagai sektor ketiga (third sector). ${ }^{11}$ Kedua, aset yang diwakafkan harus terus terpelihara dan berkembang. Hal ini nampak dengan adanya larangan terhadap pengurangan aset wakaf dan membiarkannya terlantar tanpa dimanfaatkan.

Menurut al-Jamal, seperti halnya zakat, wakaf dapat membantu setiap orang untuk berkesempatan mengolah aset-aset produktif serta mengoperasikan kemampuan yang terabaikan, sehingga pengangguran dapat dihilangkan secara bertahap. Di mana semua individu menjadi orang yang produktif. ${ }^{12}$ Ini berarti wakaf dapat mengentaskan pengangguran.Wakaf berpartisipasi aktif dalam memperbaiki ekonomi dan sosial dan masalah pengangguran. Karena itu, harta wakaf bisa dieksploitasi dalam skala besar sehingga bisa diberikan subsidi, penyediaan kesempatan kerja, dan penyediaan lembaga-lembaga pelatihan kewirausahaan.

\section{Penciptaan Keadilan Distributif}

Dalam sejarahnya, substansi wakaf uang sebenarnya telah lama muncul. Bahkan, dalam kajian fiqih klasik seiring dengan munculnya ide revitalisasi fiqih muamalah dalam perspektif maqâshid syarî́ah yang bermuara pada mashlahah al-mursalah, termasuk upaya mewujudkan kesejahteraan sosial melalui keadilan distribusi pendapatan dan kekayaan.

Wakaf uang adalah salah satu sumber pendanaan alternatif untuk program penang-

\footnotetext{
${ }^{10}$ Al-Jamal, Daur Nizhâm al-Waqf al-Islâmî, h. 165.

${ }^{11}$ Monzer Kahf, "Financing the Develpoment of Awqaf Property," makalah disampaikan pada Seminar Development of Awqaf (Kuala Lumpur 2-4 Maret 1998), h. 8-9.

${ }^{12}$ Al-Jamal, Daur Nizhâm al-Waqf al-Islâmî, h. 135.
} 
gulangan kemiskinan. ${ }^{13}$ Dengan menggalang dana wakaf uang dari orang-orang yang mampu, yang mempunyai kesadaran dan kepedulian sosial yang tinggi memberikan peluang kepada masyarakat untuk mendapatkan dan meningkatkan pendapatan. Wakaf yang terhimpun, dikelola secara produktif, kemudian keuntungannya disalurkan sebagai modal usaha kepada orang-orang yang kekurangan modal. Dari wakaf uang ini betapa banyak petani dan pedagang kecil yang mendapat tambahan modal usaha, betapa banyak orang yang hidup di bawah garis kemiskinan dapat merasakan manfaatnya.

Dengan demikian, tidak diragukan lagi bahwa wakaf memberi banyak manfaat bagi kehidupan masyarakat baik sosial maupun ekonomi. Dari perspektif sosial, wakaf dapat digunakan sebagai sarana untuk mengurangi kemiskinan, kontrol dan keharmonisan kehidupan sosial, serta meningkatkan perpaduan sosial. Wakaf dapat menghindari jarak kelas sosial antara orang kaya dan miskin karena orang yang mampu secara sukarela membagikan kekayaan mereka pada orang yang kurang mampu. Dana yang disalurkan ke lembaga pengelola wakaf dikelola secara produktif, yang kemudian surplus pengelolaannya disalurkan kepada orang-orang yang kekurangan modal usaha. Dengan demikian, seperti yang ditegaskan Duddy Roesmara Donna dan Mahmudi, produktivitas wakaf akan memicu terciptanya keadilan sosial yang dengan segera dapat menciptakan dukungan bagi kemakmuran masyarakat. ${ }^{14} \mathrm{Di}$ sini terlihat adanya bentuk distribusi pendapatan dari pihak yang mempunyai pendapatan yang lebih kepada pihak yang berpendapatan rendah. Dari efek distribusi pendapatan ini jelas akan membuat pemerataan pendapatan secara adil.

Inilah yang membedakan antara sistem ekonomi Islam dengan sistem ekonomi kapitalis yang memberikan kebebasan kepada setiap individu dalam kegiatan ekonomi tanpa batas. Dalam sistem ekonomi kapitalis, individu mempunyai kuasa penuh terhadap hartanya dan bebas menggunakan sumber-sumber ekonomi menurut cara yang dikehendaki. Prinsip kebebasan mutlak ini menurut Afzalurrahman dalam Economic Doctrines of Islam, ternyata menimbulkan ketimpangan ekonomi, membawa pada rusaknya keseimbangan dalam distribusi kekayaan di tengah masyarakat. Individu yang memiliki modal lebih besar akan menikmati hak kebebasan yang lebih baik dan mendapatkan hasil yang maksimal. ${ }^{15}$ Kondisi ini praktis membawa masyarakat kepada dua kelas, yaitu kelas hartawan dan kelas miskin. Kelas hartawan menguasai seluruh sumber-sumber produksi dan dapat bertindak sekehendak

\footnotetext{
${ }^{13}$ Selama ini, dana pengentasan kemiskinan bersumber antara lain dari 1) Pemerintah pusat, yang disalurkan melalui departemen-departemen dan pemerintah daerah (pemda). 2) Pihak luar negeri, yang disalurkan melalui pemerintah, organisasi-organisasi kemasyarakatan, LSM dan ada yang disalurkan secara langsung kepada pihak yang membutuhkan. 3) Perusahaan swasta, yang disalurkan melalui badan-badan amal, yayasan-yayasan, CSR. 4) Masyarakat, dikumpulkan melalui BAZIS (Badan Amal Zakat, Infak dan Sedekah) berupa zakat, infak dan sedekah masyarakat. Masyita, et al., "A Dynamic Model for Cash Waqf Management, h. 27.

${ }^{14}$ Donna dan Mahmudi, The Dynamic Optimization.

${ }^{15}$ Afzalurrahman, Doktrin Ekonomi Islam, terj. Soeroyo dan Nastangin (Yogyakarta: Darma Bakti Wakaf, 1985), h. 4-5.
} 
hatinya dan memanfaatkan sumber-sumber produksi untuk kepentingan pribadinya. Keadaan ini menutup peluang bagi kelas miskin untuk memperoleh bagian dari sumbersumber produksi kecuali hanya untuk memperoleh pendapatan untuk memenuhi kebutuhan minimal guna mempertahankan kelangsungan hidup sehari-hari yang diperoleh dari jasa melayani kepentingan kaum hartawan.

Untuk mengurangi beban pemerintah dan rakyat, model wakaf uang sangat tepat dalam bentuk melancarkan ketersumbatan fungsi financial intermediary. Terjadinya arus lancar (cash flow) penyaluran dana ke seluruh anggota masyarakat. Sebagaimana disebutkan al-Qur'an terhadap pelarangan konsentrasi kekayaan pada segelintir anggota masyarakat (dûlah bain al-aghniyấ) serta resistensi terhadap status idle (menganggur) bagi segenap sumber daya dan aset yang bertentangan dengan konsep produksi perspektif ekonomi Islam. Melalui wakaf uang akan terjadi proses distribusi manfaat bagi masyarakat secara lebih luas, dari manfaat pribadi (private benefit) menuju manfaat sosial (social benefit).

Sejalan dengan ini, menurut Habib Ahmed dalam Role of Zakat and Awqaf in Poverty Alleviation, dana wakaf juga dapat diberikan sebagai pinjaman kepada masyarakat yang kurang mampu. Seperti halnya zakat, wakaf dapat digunakan untuk pembiayaan sektor mikro. Keuntungan dari wakaf pun di samping sedekah dapat juga digunakan untuk pembiayaaan produktif sektor mikro. ${ }^{16}$ Wakaf uang yang dinvestasikan dalam format mudhârabah dapat membangkitkan pendapatan dari investasi yang digunakan untuk tujuan sukarela. Porsi bagi hasil untuk fund manager setelah dikurang biaya operasional dapat disalurkan untuk kebutuhan konsumtif dalam menunjang kesejahteraan kaum dhuafa melalui wasiat wakif ataupun tanpa wasiatnya.

\section{Dimensi Sosial dalam Wakaf Uang}

Instrumen wakaf yang ditawarkan Islam merupakan perwujudan dari aspek moral yang menekankan kepada nilai keadilan yang salah satu bentuknya terlihat pada keadilan sosial ekonomi. Konsep keadilan sosial ekonomi dalam perspektif Islam, didasarkan pada ajaran persaudaraan yang melampaui batas-batas geografis, suku, agama, dan ras. Hal ini dapat menciptakan hubungan antara sesama manusia hidup berdampingan secara damai dan bersahabat. Tentunya ini dapat diartikan sebagai bentuk dari universalitas Islam sebagai rahmat bagi semua umat (raḩmatan lil 'âlamîn). Keadilan sosial ekonomi (economic social justice) mengandung pengertian bahwa Islam sangat menekankan persamaan manusia (egalitarianisme) dan menghindarkan segala bentuk kepincangan sosial yang berpangkal dari kepincangan ekonomi, seperti eksploitasi, keserakahan, konsentrasi harta pada segelintir orang, dan lain-lain.

${ }^{16} \mathrm{Habib}$ Ahmed, Role of Zakat and Awqaf in Poverty Alleviation (Jedah: Islamic Research and Training Institution, Islamic Development Bank, 2004), h. 127. 
Inilah yang membedakan sistem ekonomi Islam dengan sistem ekonomi kapitalis, ${ }^{17}$ akibat dari prinsip kebebasan mutlaknya ternyata menimbulkan ketimpangan ekonomi dalam masyarakat. Kondisi ini praktis membuat jurang yang dalam antara orang kaya dan orang miskin. Kesenjangan sosial tersebut mengakibatkan nilai-nilai persaudaraan, tolong-menolong tidak lagi berharga dan tidak dipedulikan masyarakat.

Untuk menciptakan keadilan sosial ekonomi di dalam masyarakat, instrumen wakaf merupakan salah satu jawabannya. Wakaf dapat menjadi penunjang pembangunan ekonomi masyarakat. Karena di dalam instrumen wakaf, tercipta semangat tolong menolong (tấâun) dan mengandung unsur pemenuhan kewajiban individu untuk diberikan kepada masyarakat. Terciptanya keadilan sosial ekonomi akan dapat menghindarkan manusia dari kesenjangan-kesenjangan di antara sesamanya. Salah satunya adalah kesenjangan pendapatan dalam masyarakat.

Menurut al-Jamal, wakaf adalah salah satu bentuk jaminan sosial yang efektif dan sarana yang manjur untuk memerangi sikap konsumtif yang berlebihan. Wakaf juga dianggap sebagai penopang solidaritas sosial, dan salah satu media untuk mengatasi masalah kemiskinan di dalam masyarakat. Wakaf, shadaqah jâriyah yang selalu mengalirkan pahalanya kepada wakif, menjalankan sebuah peranan yang besar di bidang solidaritas sosial dalam masyarakat Islam, multi-aspek dan multi-dimensi. Ungkapan ini merupakan wujud nyata dari semangat solidaritas sosial yang secara hakiki digarap Islam dari dalam diri manusia, serta menjadikannya sebagai sistem sosial yang terpenting. Solidaritas yang terpusat pada wakaf dianggap lebih maju dibanding dengan sistem jaminan sosial yang banyak dipraktikkan pada masa sekarang ini. Sebab wakaf adalah kebajikan dan shadaqah mâliyah yang dilakukan oleh orang kaya dan memberi kemudahan untuk para fakir, miskin dan orang lemah, demi mengharap pahala di sisi Allah SWT. ${ }^{18}$

Wakaf merupakan pondasi yang didasari oleh kebajikan. Dalam sejarah peradaban Islam, Rasulullah adalah orang pertama yang memberikan contoh terbaik bagi umatnya untuk hal tersebut. Ia mewakafkan tujuh kebun yang diwasiatkan oleh seorang Yahudi yang bernama Mukhairiq. Ini merupakan wakaf pertama dari kalangan non-Muslim. Rasullullah kemudian mewakafkan sebagian hasilnya untuk kepentingan umat Islam. ${ }^{19}$ Aspek-aspek kebaikan, serta jaminan sosial yang muncul dari wakaf dalam masyarakat Islam sangat banyak. Di antaranya, wakaf diperuntukkan bagi anak terlantar dan anak yatim, serta untuk menjaga orang lumpuh, orang buta, orang jompo dan orang lemah. ${ }^{20}$ Wakaf

${ }^{17}$ Afzalurrahman, Doktrin Ekonomi Islam, h. 2; Abû al-A'la al-Maudûdî, Dasar-dasar Ekonomi dalam Islam dan Berbagai Sistem Masa Kini, terj. Abdullah Suhaili (Bandung: Al-Ma'arif, 1984), h. 7 .

${ }^{18}$ Al-Jamal, Daur Nizhâm al-Waqf al-Islâmî, h. 159.

${ }^{19}$ Lihat Monzer Kahf, Al-Waqf al-Islâmî Tathawwaruh, Idâratuh, Tanmiyatuh (Damaskus: Dâr al-Fikr, 2000), h. 19-22.

${ }^{20}$ Al-Jamal, Daur Nizhâm al-Waqf al-Islâmî, h. 160. 
dalam sejarah Islam memainkan peranan yang penting dalam kehidupan sosial ekonomi masyarakat.

Wakaf ditujukan untuk mendukung kebutuhan masyarakat miskin atau kebutuhan yang lebih luas seperti pendidikan, pelayanan kesehatan, penelitian ilmiah, perpustakaan, perlindungan lingkungan hidup, fasilitas umum pembiayaan bisnis, dan sebagainya. ${ }^{21}$ Di antara efek yang ditumbuhkan wakaf adalah berupa good deed effect, yakni efek yang berkaitan dengan moral. Orang-orang yang menyalurkan wakaf adalah orang-orang yang sangat konsern dengan kemakmuran orang-orang yang ada di sekitarnya. Seperti yang dikemukakan M.A. Mannan, motivasi konsumsi ini digerakkan oleh motivasi berbuat amal saleh (good deed). Pembelanjaan hasil wakaf mempunyai implikasi good deed effect, yakni sekali sumbangan diserahkan, sumbangan tersebut dianggap sebagai amal baik. Kepuasaan seseorang dengan memberikan sumbangan tersebut tidak tergantung dari hasil materi yang diperolehnya. Akan tetapi sangat tergantung pada banyaknya manfaat yang dapat diperoleh dengan memberikan sumbangan tersebut. ${ }^{22}$

Misalnya wakaf yang disalurkan untuk pembangunan fasilitas rumah sakit, berapa banyak manfaat yang dihasilkan dengan membangun rumah sakit yang dapat memberikan layanan kesehatan kepada fakir miskin, ketimbang membangun gedung pertunjukan seni. Apalagi Islam menyarankan agar seseorang selalu menafkahkan harta yang sangat dicintainya di jalan kebaikan (Q.S. Âli 'Imrân/3: 92). Dengan ungkapan lain, motivasi utama seseorang untuk berderma adalah karena motivasi agama. Survei yang dilakukan PIRAC (Public Interest Research and Advocacy Center) tahun 2000 di 11 kota besar di Indonesia menemukan bahwa ajaran agama sangat dominan (99\%) memengaruhi seseorang untuk berderma. ${ }^{23}$

Wakaf uang membuka peluang penciptaan investasi di bidang keagamaan, pendidikan, dan pelayanan sosial. Tabungan dari masyarakat dapat dimanfaatkan melalui penukaran sertifikat wakaf uang, sedangkan pendapatan yang diperoleh dari pengelolaan wakaf uang tersebut dapat dibelanjakan untuk berbagai keperluan yang beragam, seperti pemeliharaan harta wakaf yang ada. ${ }^{24}$ Wakaf uang pun dapat mengubah paradigma masyarakat yang memandang bahwa kewajiban wakaf hanya atas orang kaya saja. Wakaf uang dapat dilakukan oleh semua elemen masyarakat, karena sertifikat wakaf uang dapat

${ }^{21}$ Donna dan Mahmudi, The Dynamic Optimization of Cash Waqf Management, h. 2.

${ }^{22}$ M.A. Mannan, Cash-Waqf Certificat Global Opportunity for Developing the Social Market in $21^{\text {st }}$ Century Voluntary Sector Banking, Proceeding of the Third Harvard University Forum on Islamic Finance, Cambridge, Massachussets, Harvard University, 30 September-2 Oktober 1999, h. 250.

${ }^{23}$ Zaim Saidi dan Hamid Abidin, Menjadi Bangsa Pemurah Wacana dan Praktek Kedermawanan Sosial di Indonesia (Jakarta: PIRAC, 2004), h. 79.

${ }^{24}$ M.A. Mannan, "Mobilization Efforts Cash Waqf Fund at Local, National and International Levels for Development of Social Infrastructure of the Islamic Ummah and Establishment of World Sosial Bank," makalah disampaikan dalam International Seminar on Awqaf 2008; Awqaf: The Sosial and Economic Empowerment of the Ummah, Malaysia, 11-12 Agustus 2008, h. 8. 
dibuat dalam pecahan yang lebih kecil. Ini berarti masyarakat luas dapat berpartisipasi dalam pembangunan sosial.

Menurut M.A. Mannan, unsur esensial wakaf berupa keputusan penahanan diri dari menggunakan aset milik yang disertai dengan penyerahan kepada kemaslahatan publik menyiratkan tujuan pemanfaatannya secara optimal untuk kesejahteraan masyarakat luas secara permanen dan kontiniu, seperti doktrin amal jariah. Untuk menjembatani konsep tersebut, model Cash WaqfCertificate dianggap sangat tepat dalam mewujudkan kesejahteraan sosial dan membantu merangsang pertumbuhan ekonomi di tingkat masyarakat bawah.

Belajar dari negara Bangladesh, melalui Sosial Investment Bank Limited (SIBL), Bangladesh menggalang dana dari orang-orang kaya untuk dikelola dan disalurkan kepada rakyat dalam bidang pendidikan, kesehatan, dan kesejahteraan sosial melalui mekanisme produkfunding baru berupa sertifikat wakaf uang (Cash Waqf Certificate). Dalam instrumen keuangan baru ini, sertifikat wakaf uang merupakan alternatif pembiayaan yang bersifat sosial dan bisnis. Penerapan instrumen sertifikat wakaf uang ini mampu menjadi salah satu alternatif sumber pendanaan sosial. ${ }^{25} \mathrm{Hal}$ itulah yang telah dibuktikan Tabung Wakaf Indonesia (TWI) dengan mengerahkan dana wakaf dari masyarakat untuk dikelola secara produktif yang kemudian hasilnya disalurkan untuk layanan kesehatan dan pendidikan.

Adapun dimensi sosial yang termuat dalam wakaf dapat dilihat dari terciptanya sarana layanan sosial, sarana pendidikan, dan layanan kesehatan yang dapat meningkatkan kesejahteraan masyarakat secara komprehensif.

\section{Layanan Sosial}

Para ahli sejarah menyebutkan, seperti yang dikutip al-Jamal dalam Daur Nizhâm al-Waqf al-Islâmî fí al-Tanmiyah al-Iqtishâdiyah al-Mu'âshirah, Shalah al-Dîn al-Ayyûbi membuat saluran air yang mengalirkan susu dan air gula di salah satu gerbang benteng di Damaskus didanai dari wakaf. Ada juga wakaf untuk penginapan bagi para tamu, wakaf untuk melunasi utang-utang orang yang kesulitan, wakaf untuk pinjaman lunak (qardh al-ḩasan), serta wakaf untuk menyediakan benih pertanian dan irigasi. Di Mekah juga dibangun saluran air yang berasal wakaf Sayyidah Zubaidah, istri Hârun al-Rasyîd, yang dikenal dengan 'Ain Zubaidah (Mata Air Zubaidah) ${ }^{26}$ Semua wakaf dan lembaga kebajikan sosial yang muncul menunjukkan peranan besar yang diemban oleh wakaf di bidang pengamanan sosial dan pengentasan kemiskinan.

Sayyid Quthb (w. 1966), pemikir Islam dari Mesir dengan gaya pendekatan komprehensif dalam bukunya Al-Adâlah al-Ijtimấìyah fí al-Islâm, seperti yang dikutip Umer Chapra berhasil memformulasikan teori keadilan sosial dalam Islam dan instrumen pendukungnya,

${ }^{25}$ Ibid., h. 7-8.

${ }^{26}$ Al-Jamal, Daur Nizhâm al-Waqf al-Islâmî, h. 160. 
termasuk wakaf, bukan sebatas teori utopis belaka, melainkan kajiannya berangkat dari fakta sejarah peradaban Islam. Setelah mengupas pandangan Islam mengenai kasih sayang, kebajikan, keadilan, dan jaminan sosial yang menyeluruh antara orang yang mampu dan tidak mampu, antara kelompok yang kaya dan miskin, antara individu dan masyarakat, antara pemerintah dan rakyat, bahkan antara segenap umat manusia. Quthb selalu membeberkan fakta historis bagaimana konsep tersebut membumi dalam perjalanan sejarah Islam. ${ }^{27}$

Sebagai contoh, sepenggal fragmen sejarah solidaritas sosial di kalangan Sahabat seperti Abû Bakar Shiddiq, 'Umar ibn al-Khaththâb, 'Utsmân ibn 'Affân dan 'Alî ibn Abî Thâlib. Di antara impelementasi keadilan sosial melalui prakarsa wakaf dalam pengalaman kesejarahan awal Islam telah dibuktikan 'Umar ibn al-Khaththâb sebagai warga sederhana bersedia secara ikhlas atas petunjuk Nabi Muhammad SAW. untuk mewakafkan satu-satunya aset berharga yang dimilikinya berupa sebidang tanah di Khaibar untuk kemaslahatan umat. 'Usman ibn 'Affân juga membeli sumur dan mewakafkannya untuk kepentingan kaum muslim. ${ }^{28}$ Quthb menawarkan sebuah tantangan bagi umat Islam untuk mengulang pengalaman sejarah dalam mewujudkan kembali cita-cita keadilan sosial dengan modal populasi umat yang begitu besar di wilayah Afrika, Pakistan dan Indonesia. Menurutnya, hal itu sangat potensial memberi kontribusi bagi kesejahteraan sosial secara luas. ${ }^{29}$

\section{Layanan Kesehatan}

Adapun wakaf yang berhubungan dengan layanan kesehatan, al-Jamal memaparkan bahwa wakaf telah memberikan kontibusi positif di seluruh negeri Islam, misalnya dalam bentuk pembangunan rumah sakit, laboratorium, dan gaji para dokter dan pembantunya dan pelayanan kesehatan bersumber dari wakaf. Dengan wakaf universitas kedokteran dan pengembangan studi farmasi dan kimia pun telah didirikan. Para peneliti telah membuktikan bahwa banyak dari pusat-pusat pelayanan kesehatan dan rumah rumah sakit yang tersebar di seluruh kota dan negeri Islam ditopang oleh wakaf. Rumah sakit umum pertama dalam sejarah Islam seperti di al-Bimaristan dan di Baghdad pada masa Harun al-Rasyid dibangun dari wakaf. Rumah sakit istri khalifah al-Muqtadir Billah, yang dinamakan dengan Rumah Sakit al-Sayyidah yang dibuka pada 1 Muharram $203 \mathrm{H}$ pun dibangun dari harta wakaf. ${ }^{30}$

Di Mesir rumah sakit pun banyak dibangun dengan harta wakaf, seperti rumah sakit yang didirikan oleh al-Fath ibn Khafan, pada masa Dinasti Abbasiyah al-Mutawakkil 'Alallah,

\footnotetext{
${ }^{27}$ Muhammad Umer Chapra, Masa Depan Ilmu Ekonomi: Sebuah Tinjauan Islam, terj. Ikhwan Abidin Basri (Jakarta: Gema Insani Press, 2001), h. 58.

${ }^{28} \mathrm{Kahf}$, Al-Waqf al-Islâmî, h. 19-22.

${ }^{29}$ Chapra, Masa Depan Ilmu Ekonomi, h. 58

${ }^{30}$ Ibid., h. 149-150.
} 
rumah sakit yang didirikan oleh Ahmad bin Thulân, demikian juga rumah sakit yang dibangun oleh Shalahuddin al-Ayyubi dibiayai dari wakaf. ${ }^{31}$

\section{Sarana Pendidikan}

Di samping itu, wakaf uang juga dapat disalurkan untuk membantu lembaga pendidikan yang selalu kekurangan biaya operasional, melalui pemberian beasiswa kepada peserta didik dan insentif untuk pengelola sekolah. Profit dari wakaf uang dapat membantu bagi pendirian ataupun operasionalisasi lembaga-lembaga pendidikan, rumah sakit, termasuk masjid, dan lembaga sosial lainnya. Dengan adanya lembaga yang konsern terhadap pengelolaan wakaf uang, kontribusi dalam mengatasi problem kemiskinan dan kebodohan yang mendera bangsa akan lebih signifikan, seperti yang sudah dicapai oleh Wizârat al-Awqâf kerajaan Yordania dari pengembangan wakaf dapat: 1) Membuka lembaga pendidikan tinggi seperti Fakultas Dakwah, Syariah dan Ushuluddin; 2) Mendirikan beberapa lembaga pendidikan di Amman dan Yerussalem, Junain, Khalil dan Qalqiliyyah; 3) Mendirikan 53 tempat belajar al-Qur'an dan Hadis; 4) Mengalokasikan dana wakaf pada madrasah, rumah yatim piatu; 5) Mendirikan percetakan mushaf al-Quran; 6) Mendirikan 250 perpustakaan mesjid; dan 7) Memberikan beasiswa untuk belajar di Universitas Yordan. ${ }^{22}$

Sama halnya yang dilakukan Universitas al-Azhar di Kairo, Mesir, yang telah berusia lebih dari 1.000 tahun terkenal dengan wakafnya yang teramat besar. Bukan hanya wakaf tanah, gedung dan lahan pertanian, tetapi juga wakaf uang. Dengan wakaf yang amat besar itu, Universitas mampu membiayai operasional pendidikannya selama berabad-abad tanpa bergantung pada pemerintah maupun pembayaran SPP siswa dan mahasiswanya. ${ }^{33}$ Bahkan, universitas ini mampu memberikan beasiswa kepada ribuan mahasiswa dari seluruh penjuru dunia selama berabad-abad. Hampir sekitar 300 sekolah dasar di Jazirah Shaqliyah (Sicilia) seluruhnya merupakan harta wakaf, dan seluruh studi dibiayai dari pendapatan wakaf. Kemudian, beberapa universitas terkemuka, di antaranya Universitas Qarawiyyin di Fes, Marokko, Universitas al-Azhar di Kairo, Universitas-universitas Nizhamiyah dan Mushtanshiriyah di Baghdad didirikan dengan harta wakaf. ${ }^{34}$

Di Indonesia, wakaf sebagai sarana penopang lembaga pendidikan sudah dibuktikan oleh beberapa yayasan yang konsern melakukan pengelolaan wakaf produktif, seperti

${ }^{31}$ Amin, Al-Awqâf wa al-Hayât, h. 155-156; Al-Jamal, Daur Nizhâm al-Waqf al-Islâmî, h. 150.

${ }^{32}$ Uswatun Hasanah, "Pemanfaatan Wakaf di Yordania," dalam Modal No. 19/II-Mei 2004.

${ }^{33}$ Pada tahun 1961, Pemerintah Mesir di bawah kepemimpinan Presiden Abdul Nasser, melakukan nasionalisasi secara paksa atas seluruh harta wakaf al-Azhar. Al-Azhar pun kemudian dijadikan bagian struktur negara, anggarannya ditetapkan dan diberikan oleh negara. Lihat Azyumardi Azra, "Memotret Filantropi di Indonesia," pengantar dalam buku Zaim Saidi dan Hamid Abidin, Menjadi Bangsa Pemurah Wacana dan Praktek Kedermawanan Sosial di Indonesia (Jakarta, Piramedia, 2004), h. vii-viii.

${ }^{34}$ A-Jamal, Daur Nizhâm al-Waqf al-Islâmî, h. 143. 
yang dilakukan Badan Wakaf Universitas Islam Indonesia dan Pondok Pesantren Gontor. TWI pun menyalurkan dana wakaf uang yang diperuntukkan bagi pendidikan gratis di Smart Ekselensia Indonesia. Ini berarti bahwa wakaf tidak hanya untuk penyediaan bangunanbangunan universitas-universitas dan sekolah-sekolah, tetapi juga menyediakan sarana dan prasana belajar mengajar, perpustakaan, asrama, beasiswa bagi para pelajar, termasuk gaji guru.

\section{Penutup}

Dari bukti-bukti di atas jelaslah bahwa harta wakaf sangat berperan dalam membangun pendidikan dan menyemarakkan gerakan ilmiah dalam peradaban Islam. Sejarah banyak menyebutkan kebesaran dan kekaguman pada kaum Muslim seperti Shalah al-Dîn alAyyûbi, yang mengulurkan bantuan untuk pembangunan sekolah-sekolah di seluruh kota. ${ }^{35}$

Tidak mengherankan jika M.A. Mannan menegaskan bahwa wakaf uang berfungsi sebagai investasi yang strategis untuk menghapus kemiskinan dan menangani ketertinggalan di bidang ekonomi, pendidikan, kesehatan, dan riset. ${ }^{36}$ Dengan ikut serta dalam program ini, menurut pendiri Sosial Investment Bank Ltd. (SIBL) Bangladesh itu, seseorang telah memberikan kontribusi tidak hanya bagi pengembangan operasional social capital market, tetapi juga di bidang investasi sosial permanen. Dana yang terhimpun dari wakaf uang diinvestasikan sehingga dapat memberikan jaminan sosial dan ekonomi kepada masyarakat secara keseluruhan. Wakaf uang yang sudah dikenal sejak zaman Usmaniyah tersebut, merupakan inovasi dalam keuangan publik Islam (Islamic Public Finance). Tergalinya potensi dana wakaf yang dahsyat ini sangat diharapkan mensejahterakan masyarakat secara terkoordinasi, sinergis, sitematis, dan profesional. Di samping itu, tantangan integritas amanah dan kepercayaan (trust) bagi pengelolaan dana sosial (volunteer) menjadi pemikiran bersama untuk mewujudkan bentuk yang fit and proper bagi penerapan konsepnya.

Dengan demikian wakaf uang terbukti dapat dijadikan sebagai penunjang proses pembangunan secara menyeluruh, baik dalam pembangunan sumber daya manusia, maupun dalam pembangunan ekonomi dan sosial. Melalui investasi wakaf uang di sektor riil, wakaf dapat mewujudkan keadilan distributif di tengah masyarakat. Wakaf uang dapat dijadikan instrumen penanganan masalah perekonomian negara dengan menciptakan pemerataan dan peningkatan pertumbuhan ekonomi masyakarat melalui pembiayaan micro finance. Di samping itu wakaf uang mampu meningkatkan kualitas sumber daya insani dengan menciptakan keadilan sosial bidang pengadaan sarana layanan sosial, layanan kesehatan, dan pendidikan.

143.

${ }^{35}$ Amin, al-Awqâf wa al-Hayât, h. 234-235; Al-Jamal, Daur Nizhâm al-Waqf al-Islâmî, h.

${ }^{36}$ Mannan, Mobilization, h. 9; Masyita et al., A Dynamic Model for Cash Waqf Management. 


\section{Pustaka Acauan}

Afzalurrahman. Doktrin Ekonomi Islam, terj. Soeroyo dan Nastangin. Yogyakarta: Darma Bakti Wakaf, 1985.

Ahmed, Habib. Role of Zakat and Awqaf in Poverty Alleviation. Jeddah: Islamic Research and Training Institution, Islamic Development Bank (IDB), 2004.

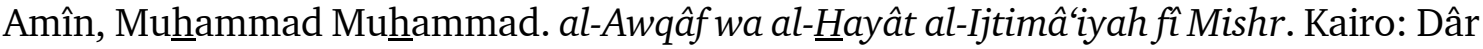
al-Nahdhah al-Arabiyah al-Qahirah, t.t.

Azra, Azyumardi. "Memotret Filantropi di Indonesia," dalam Zaim Saidi dan Hamid Abidin. Menjadi Bangsa Pemurah Wacana dan Praktek Kedermawanan Sosial di Indonesia. Jakarta, Piramedia, 2004.

Chapra, Muhammad Umer. Masa Depan Ilmu Ekonomi: Sebuah Tinjauan Islam, terj. Ikhwan Abidin Basri. Jakarta: Gema Insani Press, 2001.

Cizakca, Murat. "Awqaf in History and Its Implications for Modern Islamic Economic," Islamic Economic Studies, Vol. 6 No. 1 November 1998. Jedah: Islamic Research and Training Institution (IRTI) Islamic Development Bank (IDB).

Cizakca, Murat. "Incorporated Cash Waqfs: Islamic Non-Bank Financial Instruments from the Past to the Future?," dalam Cash Waqf and Benefits for Future Generations, Incef the Global University Islamic Finance, www.mcizakca.com/publications.htm, Diunduh_29 Juli 2009, 15.38 WIB.

Departemen Agama RI. Wakaf Tunai dalam Perspektif Hukum Islam. Jakarta: Direktorat Jenderal Bimbingan Islam dan Penyelengaraan Haji Direktorat Pengembangan Zakat dan Wakaf, 2005.

Departemen Agama RI. Undang-Undang Nomor 41 Tahun 2004 Tentang Wakaf. Jakarta: t.p., 2007.

Donna, Duddy Roesmara dan Mahmudi. The Dynamic Optimization of Cash Waqf Management: an Optimal Control Theory Approach, http://psekp.ugm.ac.id, h 2, Diunduh 18 Juni, 2007, 13.07 WIB.

Hasanah, Uswatun. "Pemanfaatan Wakaf di Yordania," Majalah Modal No. 19/II-Mei 2004.

http://www.halalguide.info. "Wakaf Produktif," Diunduh 6 Juni, 2007, 18.54 WIB.

Isbir, "Wakaf Tunai” http://bimasislam.depag.go.id, Diunduh 19 Desember 2007, 10.53 WIB.

Al-Jamâl, Ahmad Muhammad 'Abd al-`Azhim. al-Waqfal-Islâmîfi al-Tanmiyah al-Iqtishâdiyah al-Mu 'âshirah. Kairo: Dâr al-Salâm, 2007.

Kahf, Monzer. "Financing the Development of Awqaf Property," makalah disampaikan pada Seminar Development of Awqaf, Kuala Lumpur 2-4 Maret 1998.

Kahf, Monzer, Al-Waqf al-Islâmî Tathawwaruh, Idâratuh, Tanmiyatuh, Damaskus: Dâr alFikr, 2000.

Mannan, Muhammad Abdul, Cash-Waqf Certificate Global Opportunity for Developing the

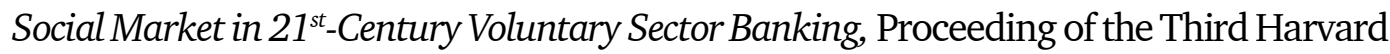


University Forum on Islamic Finance, Cambridge, Massachussets, Harvard University, 30 September-2 Oktober 1999.

Mannan, Muhammad Abdul, Mobilization Efforts Cash Waqf Fund at Local, National and International Levels for Development of Social Infrastructure of the Islamic Ummah and Establishment of World Social Bank, makalah disampaikan dalam International Seminar on Awqaf 2008; Awqaf: The Social and Economic Empowerment of the Ummah, Malaysia, 11-12 Agustus 2008.

Masyita, Dian, et al. "A Dynamic Model for Cash Waqf Management as One of The Alternative Instruments for The Poverty Alleviation in Indonesia," makalah disampaikan pada The 23rd International Conference of The System Dynamics Society Massachussets Institute of Technology (MIT), Boston, Juli 17-21, 2005.

Al-Maudûdî, Abû al-A'la. Dasar-dasar Ekonomi dalam Islam dan Berbagai Sistem Masa Kini, terj. Abdullah Suhaili. Bandung: Al-Ma'arif, 1984.

Nasution, Mustafa Edwin. Wakaf Tunai dan Sektor Volunter: Strategi untuk Mensejahterakan Masyarakat dan Melepaskan Ketergantungan Utang Luar Negeri, Makalah disampaikan dalam Seminar Wakaf Tunai-Inovasi Finansial Islam: Peluang dan Tantangan dalam Mewujudkan Kesejahteraan Sosial, Jakarta: 10 November 2001.

Saidi, Zaim dan Hamid Abidin. Menjadi Bangsa Pemurah Wacana dan Praktek Kedermawanan Sosial di Indonesia. Jakarta: PIRAC, 2004. 